\title{
An empirical investigation on factors influencing sales force
}

\author{
Naser Azad $^{\mathrm{a}^{*}}$, Ozhan Karimi ${ }^{\mathrm{b}}$ and Azadeh Salman Tabar ${ }^{\mathrm{c}}$
}

${ }^{a}$ Department of Management, Islamic Azad University, South Tehran Branch, Tehran, Iran

${ }^{b}$ Faculty Member of Payam Noor University

${ }^{c}$ Masters student of Payam Noor University, Damavand, Iran

\section{H R O N I C L E A B S T R A C T}

Article history:

Received January 12, 2013

Received in revised format

30 April 2013

Accepted 12 May 2013

Available online

May 142013

Keywords:

Factor analysis

Sales force

Diary product

\begin{abstract}
Sales force plays an important role on improving revenue growth and boosting sales' figures. This paper presents an empirical study to find important factors influencing on sales force using factor analysis. The proposed study designed a questionnaire, distributed among 353 sales force who were working for a diary producer in Iran named Kaleh. The questionnaire consists of 68 questions Cronbach alpha was calculated as 0.921 , which is well above the minimum acceptable limit and validates the results. The results of our survey indicate that seven major factors including qualification criteria, sale's motivation, personality, capability, content information, personal characteristics and personal interest played an important role on having reliable sales force.
\end{abstract}

\section{Introduction}

Sales force plays an important role on improving revenue growth and boosting sales' figures. Anderson is one of the pioneers who introduced a new theory of the firm, which attempts to specify the role of marketing and the other functional areas in the goal setting and strategic planning process. According to Barker et al. (2009), sales force automation (SFA) is described as the implementation of software to automate sales tasks, including sales activities, order processing, customer management, sales forecasting and analysis, sales force management, and information sharing. They explored the utilization of SFA, the benefits derived from these systems, and user acceptance issues. Bente et al. (2012) discussed about characteristics of sales forces and stated that reputation scores and seller photos could be regarded as two kinds of signals promoting trust in e-commerce. Buehrer et al. (2005) explored the reasons why salespeople implement SFA technologies, the perceived barriers to SFA usage and how management could increase the usage of SFA technology.

*Corresponding author.

E-mail addresses: dr.naserazad@yahoo.com (N. Azad) 
Cascio et al. (2010) demonstrated that alignment between top management and immediate supervisors' commitment to the SFA technology could be an important factor in influencing SFA adoption. Specifically, even when supervisors were committed to sales technology, lack of top management commitment could hurt SFA adoption. Cho and Chang (2008) examined the psychological and social antecedents of salespeople's resistance toward SFA technologies in South Korea. The study represented one of the very few empirical studies performed on sales force behavior in South Korea and as such may offer some insights on sales force management in collectivist cultures. Franke and Park (2006) performed an investigation on salesperson adaptive selling behavior and customer orientation using a meta-analysis.

Gohmann et al. (2005) reported the results of a study on the differences in perceptions held by the United States Army's recruiting force and its higher level management toward the Army's newly adopted SFA system, the Army Recruiting Information Support System (ARISS). They reported that there were some significant differences between the perceptions held by the recruiting force and higher level management toward ARISS, the SFA system. Holmes and Srivastava (2002) investigated the effects of job perceptions on job behaviors: implications for sales performance. Honeycutt Jr et al. (2005) identified and explained impediments, which existed in three SFA areas including planning, communication, and evaluation. The high failure rate of SFA could also be explained by gaps that exist, between the sales force and management, in SFA perceptions and goals. Johnston et al. (1990) performed a longitudinal assessment of the effect of selected organizational influences on salespeople's organizational commitment during early employment.

Keillor et al. (1997) in a comprehensive survey investigated SFA issues prior to implementation by looking into the relationship between attitudes toward technology, experience and productivity. Krishnamoorthy et al. (2005) performed an investigation on scheduling sales force training. Li (2010) tried to understand the effects of seller's and bidder's characteristics on Internet auction applications. Meehan and Wright (2011) examined power priorities by looking into a buyer-seller comparison of areas of influence. Park et al. (2010) investigated the effect of SFA usage on both customer relationship quality and sales performance. Their results highlighted the mediating role of salesperson learning and adaptive selling behaviors in the SFA usage and sales performance relationship.

Rangarajan et al. (2005) investigated the impact of sales force automation on technology-related stress, effort, and technology usage among salespeople. Outsourcing the sales force is another important factors for developing a business unit (Rapp, 2009). Ross Jr. et al. (2005) discussed whether we must set up our own sales force or outsource it. Weitz (1978) investigated the relationship between salesperson performance and understanding of customer decision making. Widmier et al. (2002) studied the effects of infusing technology into personal selling. Vlachos et al. (2010) investigated sales force reactions to corporate social responsibility and finally Venkatesh et al. (2003) investigated the user acceptance of information technology

\section{The proposed study}

The proposed study designed a questionnaire, distributed among 353 sales force who were working for a diary producer in Iran named Kaleh. The questionnaire consists of 68 questions Cronbach alpha was calculated as 0.921, which is well above the minimum acceptable limit and validates the results. Figs. 1-3 demonstrate some of the personal characteristics of the participants. As we can observe from Fig. 1, most sales forces are middle age people and according to Fig. 2, they are mostly highly educated people and according to Fig. 3 most of them had only a few years of job experiences. 


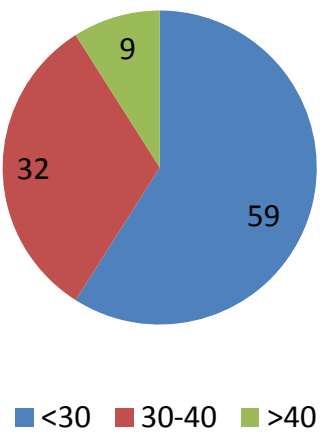

Fig. 1. Distribution of participants' age

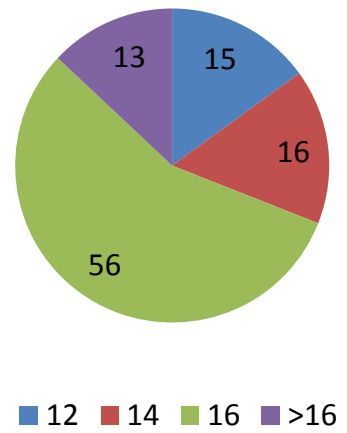

Fig. 2. Distribution of participants' educations

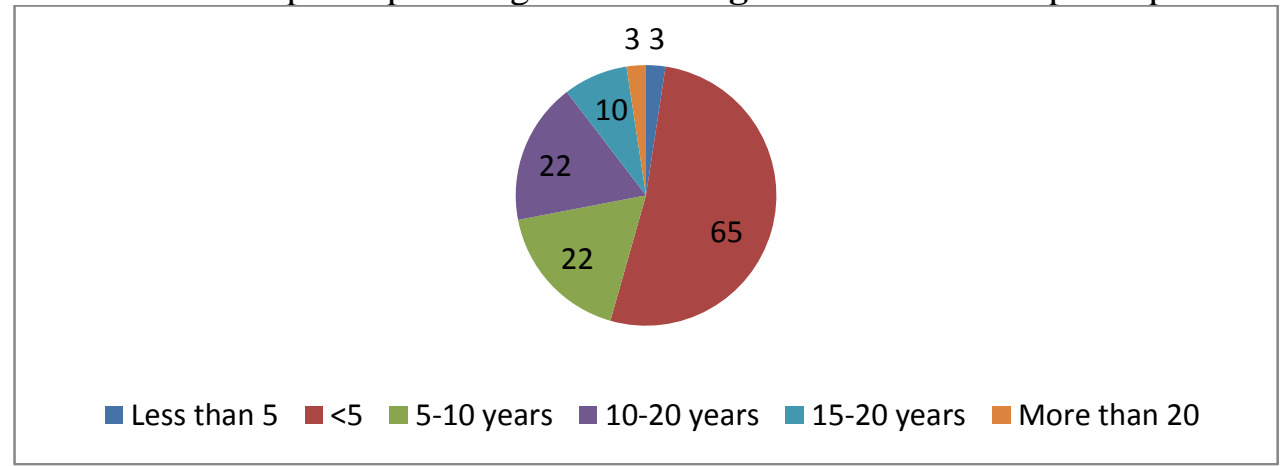

\section{The results}

Fig. 3. Distribution of participants' years of experiences

The proposed study of this paper has detected seven different factors including qualification criteria, sale's motivation, personality, capability, content information, personal characteristics and personal interest based on factor analysis and in this section, we present details of our findings.

\subsection{The first factor: qualification criteria}

The first factor is associated with qualification criteria, which consists of seven factors summarized in Table 1 as follows,

\section{Table 1}

The summary of factors associated with qualification criteria

\begin{tabular}{lcccc}
\hline \multicolumn{1}{c}{ Option } & Factor weight & Eigenvalue & \% ofvariance & Accumulated \\
\hline Sales force performance & 0.716 & 953.24 & 953.24 & 233.9 \\
Sales force's behavior & 0.667 & & \\
Top managers' commitments & 0.565 & & \\
Sales' efforts & 0.498 & & \\
Training & 0.461 & & \\
Skills & 0.356 & & \\
Personal capability of sales force & 0.320 & & & \\
\hline Cronbach alph $=0.787$ & & & &
\end{tabular}

The results of Table 1 indicate that "sales force performance" is number priority followed by "sales force's behavior" and "top managers' commitments". Cronbach alpha has been calculated as 0.787 , which is well above the minimum desirable level.

\subsection{The second factor: sales force motivation}

The second factor is associated with sales force's motivation, which consists of four factors summarized in Table 2 as follows, 
Table 2

The summary of factors associated with sales force's motivation

\begin{tabular}{lcccc}
\hline \multicolumn{1}{c}{ Option } & Factor weight & Eigenvalue & \% ofvariance & Accumulated \\
\hline Job security & 0.615 & 880.32 & 135.7 & 64.2 \\
Sales force's reputation & 0.535 & & & \\
Job satisfaction & 0.591 & & & \\
Sales' capability to answer customers' questions & 0.336 & & & \\
\hline Cronbach alph $=0.834$ & & & & \\
\end{tabular}

The results of Table 2 specify that "Job security" is number priority followed by "Job satisfaction" and "Sales force's reputation". Cronbach alpha has been calculated as 0.834 , which is well above the minimum desirable level.

\subsection{The third factor: sales force personality}

The third factor is associated with sales force's personality, which consists of three factors summarized in Table 3 as follows,

\section{Table 3}

The summary of factors associated with sales force's personality

\begin{tabular}{lcccc}
\hline \multicolumn{1}{c}{ Option } & Factor weight & Eigenvalue & \% ofvariance & Accumulated \\
\hline Sales force perception & 0.714 & 602.36 & 514.4 & 67.1 \\
Sales force's relationships & 0.676 & & & \\
Sales' forces' loyalty & 0.402 & & & \\
\hline
\end{tabular}

Cronbach alph $=0.709$

The results of Table 3 specify that "Sales force perception" is number priority followed by "Sales force’s relationships" and "Sales' forces' loyalty”. Cronbach alpha has been calculated as 0.709, which is well above the minimum desirable level.

\subsection{The fourth factor: sales force capability}

The fourth factor is associated with sales force's capability, which consists of four factors summarized in Table 4 as follows,

\section{Table 4}

The summary of factors associated with sales force's capability

\begin{tabular}{lcccc}
\hline \multicolumn{1}{c}{ Option } & Factor weight & Eigenvalue & \% ofvariance & Accumulated \\
\hline Sales force expertise & 0.622 & 903.40 & 301.4 & 591.1 \\
Sales force's technical knowledge & 0.522 & & & \\
Sales' forces' new ideas & 0.431 & & & \\
Independent sales force & 0.312 & & & \\
\hline Cronbach alph $=0.709$ & & & & \\
\hline
\end{tabular}

The results of Table 4 imply that "Sales force expertise" is number priority followed by "Sales force's technical knowledge” and "Sales' forces' new ideas”. Cronbach alpha has been calculated as 0.709, which is well above the minimum desirable level.

\subsection{The fifth factor: Information content}

The fifth factor is associated with information content, which consists of three factors summarized in Table 5 as follows,

\section{Table 5}

The summary of factors associated with content information

\begin{tabular}{lcccc}
\hline \multicolumn{1}{c}{ Option } & Factor weight & Eigenvalue & \% ofvariance & Accumulated \\
\hline Quantity of information & 0.973 & 748.44 & 844.3 & 422.1 \\
Quality of information & 0.689 & & & \\
Performance feedback & 0.516 & & & \\
\hline Cronbach alph $=0.709$ & & & &
\end{tabular}


The results of Table 5 imply that "Sales force expertise" is number priority followed by "Sales force's technical knowledge” and "Sales' forces' new ideas”. Cronbach alpha has been calculated as 0.709 , which is well above the minimum desirable level.

\subsection{The sixth factor: Personal characteristics}

The sixth factor is associated with personal characteristics, which consists of three factors summarized in Table 6 . The results of Table 6 imply that "Gender" is number priority followed by "age”. Cronbach alpha is calculated as 0.709 , which is well above the minimum desirable level.

\section{Table 6}

The summary of factors associated with Sales forces' personal characteristics

\begin{tabular}{lcccc}
\hline Option & Factor weight & Eigenvalue & $\%$ ofvariance & Accumulated \\
\hline Age & 0.668 & 346.48 & 599.3 & 331.1 \\
Gender & 0.794 & & & \\
Resistance to accept new technology & 0.425 & & & \\
\hline Cronbach alph $=0.731$ & & & &
\end{tabular}

\subsection{The seventh factor: Sales force interest}

The seventh factor is associated with sales force interest, which consists of three factors summarized in Table 7 as follows,

\section{Table 7}

The summary of factors associated with Sales forces’ interest

\begin{tabular}{lcccc}
\hline Option & Factor weight & Eigenvalue & \% ofvariance & Accumulated \\
\hline Long term profit making of sales forces & 0.744 & 641.51 & 295.3 & 219.1 \\
Domain & 0.483 & & & \\
Sales based on customers' needs & 0.356 & & & \\
Word of mouth advertisement & 0.317 & & & \\
\hline Cronbach alph $=0.773$ & & & &
\end{tabular}

The results of Table 7 imply that "Long term profit making of sales forces" is number priority and Cronbach alpha has been calculated as 0.779 , which is well above the minimum desirable level.

\section{Discussion and conclusion}

Building a brand and making profit in today's competitive market has become a tedious task and there are different factors influencing it. In this paper, we have concentrated on discovering important factors influencing sales force in one of Iranian dairy products. The proposed study of this paper has performed factor analysis to detect important factors and detected seven factors. For each factor, we have detected essential components. We believe an efficient investment on these factors will help us improve quality of sales' forces.

\section{References}

Anderson, P. F. (1982). Marketing, strategic planning and the theory of the firm. The Journal of Marketing, 15-26.

Barker, R. M., Gohmann, S. F., Guan, J., \& Faulds, D. J. (2009). Why is my sales force automation system failing?. Business Horizons, 52(3), 233-241.

Bente, G., Baptist, O., \& Leuschner, H. (2012). To buy or not to buy: Influence of seller photos and reputation on buyer trust and purchase behavior. International Journal of Human-Computer Studies, 70(1), 1-13.

Buehrer, R. E., Senecal, S., \& Bolman Pullins, E. (2005). Sales force technology usage-reasons, barriers, and support: An exploratory investigation. Industrial Marketing Management, 34(4), 389398. 
Cascio, R., Mariadoss, B. J., \& Mouri, N. (2010). The impact of management commitment alignment on salespersons' adoption of sales force automation technologies: An empirical investigation. Industrial Marketing Management, 39(7), 1088-1096.

Cho, S. D., \& Chang, D. R. (2008). Salesperson's innovation resistance and job satisfaction in intraorganizational diffusion of sales force automation technologies: the case of South Korea. Industrial Marketing Management, 37(7), 841-847.

Franke, G. R., \& Park, J. E. (2006). Salesperson adaptive selling behavior and customer orientation: a meta-analysis. Journal of Marketing Research, 693-702.

Gohmann, S. F., Guan, J., Barker, R. M., \& Faulds, D. J. (2005). Perceptions of sales force automation: Differences between sales force and management. Industrial Marketing Management, 34(4), 337-343.

Holmes, T. L., \& Srivastava, R. (2002). Effects of job perceptions on job behaviors: implications for sales performance. Industrial Marketing Management, 31(5), 421-428.

Honeycutt Jr, E. D., Thelen, T., Thelen, S. T., \& Hodge, S. K. (2005). Impediments to sales force automation. Industrial Marketing Management, 34(4), 313-322.

Johnston, M. W., Parasuraman, A., Futrell, C. M., \& Black, W. C. (1990). A longitudinal assessment of the impact of selected organizational influences on salespeople's organizational commitment during early employment. Journal of Marketing Research, 333-344.

Keillor, B. D., Bashaw, R. E., \& Pettijohn, C. E. (1997). Salesforce automation issues prior to implementation: the relationship between attitudes toward technology, experience and productivity. Journal of Business \& Industrial Marketing, 12(3/4), 209-219.

Krishnamoorthy, A., Misra, S., \& Prasad, A. (2005). Scheduling sales force training: Theory and evidence. International Journal of Research in Marketing,22(4), 427-440.

Li, C. F. (2010). Understanding effects of seller's and bidder's characteristics on Internet auction applications. Expert Systems with Applications, 37(4), 3462-3467.

Meehan, J., \& Wright, G. H. (2011). Power priorities: A buyer-seller comparison of areas of influence. Journal of Purchasing and Supply Management, 17(1), 32-41.

Park, J. E., Kim, J., Dubinsky, A. J., \& Lee, H. (2010). How does sales force automation influence relationship quality and performance? The mediating roles of learning and selling behaviors. Industrial marketing management, 39(7), 1128-1138.

Park, J. E., \& Deitz, G. D. (2006). The effect of working relationship quality on salesperson performance and job satisfaction: adaptive selling behavior in Korean automobile sales representatives. Journal of Business Research, 59(2), 204-213.

Rangarajan, D., Jones, E., \& Chin, W. (2005). Impact of sales force automation on technology-related stress, effort, and technology usage among salespeople. Industrial Marketing Management, 34(4), 345-354.

Rapp, A. (2009). Outsourcing the sales process: Hiring a mercenary sales force. Industrial Marketing Management, 38(4), 411-418.

Ross Jr, W. T., Dalsace, F., \& Anderson, E. (2005). Should you set up your own sales force or should you outsource it? Pitfalls in the standard analysis. Business Horizons, 48(1), 23-36.

Segalla, M., Rouziès, D., Besson, M., \& Weitz, B. A. (2006). A cross-national investigation of incentive sales compensation. International Journal of Research in Marketing, 23(4), 419-433.

Venkatesh, V., Morris, M. G., Davis, G. B., \& Davis, F. D. (2003). User acceptance of information technology: Toward a unified view. MIS quarterly, 425-478.

Vlachos, P. A., Theotokis, A., \& Panagopoulos, N. G. (2010). Sales force reactions to corporate social responsibility: Attributions, outcomes, and the mediating role of organizational trust. Industrial Marketing Management, 39(7), 1207-1218.

Weitz, B. A. (1978). Relationship between salesperson performance and understanding of customer decision making. Journal of Marketing Research, 501-516.

Widmier, S. M., Jackson Jr, D. W., \& McCabe, D. B. (2002). Infusing technology into personal selling. The Journal of Personal Selling and Sales Management, 189-198. 